n-Alkane lipid biomarkers in loess

M. Zech et al.

\title{
Technical Note: $n$-Alkane lipid biomarkers in loess: post-sedimentary or syn-sedimentary?
}

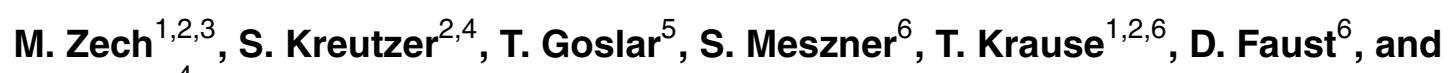
M. Fuchs ${ }^{4}$

${ }^{1}$ Department of Soil Physics, University of Bayreuth, Universitätsstr. 30, 95440 Bayreuth, Germany

${ }^{2}$ Geographical Institute, Geomorphology, University of Bayreuth, Universitätsstr. 30, 95440 Bayreuth, Germany

${ }^{3}$ Terrestrial Biogeosciences, Martin-Luther-Universität Halle-Wittenberg, Von-Seckendorff-Platz 3, 06120 Halle (Saale), Germany

${ }^{4}$ Department of Geography, Justus-Liebig-University Giessen, Senckenbergstr. 1, 35390 Giessen, Germany

${ }^{5}$ Poznan Radiocarbon Laboratory, ul. Rubiez 46, 61-612 Poznan, Poland

${ }^{6}$ Department of Geography, Chair of Physical Geography, Dresden University of Technology, Helmholtzstr. 10, 01069 Dresden, Germany

Title Page

Abstract Introduction

Conclusions References

Tables Figures

14 I

4

Back

Close

Full Screen / Esc

Printer-friendly Version

Interactive Discussion 
Received: 7 July 2012 - Accepted: 9 July 2012 - Published: 31 July 2012

Correspondence to: M. Zech (michael_zech@gmx.de)

Published by Copernicus Publications on behalf of the European Geosciences Union.

BGD

9, 9875-9896, 2012

n-Alkane lipid biomarkers in loess

M. Zech et al.

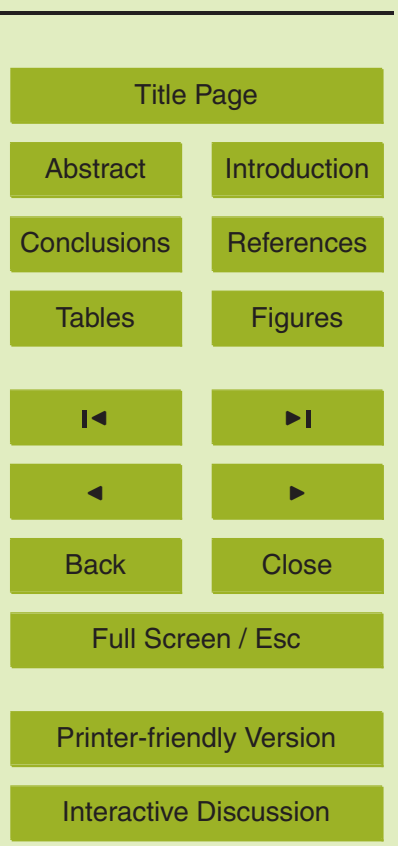




\section{Abstract}

There is an ongoing discussion whether $n$-alkane biomarkers - and organic matter (OM) from loess in general - reflect a syn-sedimentary paleoenvironmental and paleoclimate signal or whether they are significantly a post-sedimentary feature con5 taminated by root-derived OM. We present first radiocarbon data for the $n$-alkane fraction of lipid extracts and for the first time luminescence ages for the Middle to Late Weichselian loess-paleosol sequence of Gleina in Saxony, Germany. Comparison of these biomarker ages with sedimentation ages as assessed by optically stimulated luminescence (OSL) dating shows that one $n$-alkane sample features

10 a syn-sedimentary age $\left({ }^{14} \mathrm{C}: 29.2 \pm 1.4 \mathrm{kyr}\right.$ calBP versus OSL: $\left.27.3 \pm 3.0 \mathrm{kyr}\right)$. By contrast, the ${ }^{14} \mathrm{C}$ ages derived from the other $n$-alkane samples are clearly younger $(20.3 \pm 0.7 \mathrm{kyrcalBP}, 22.1 \pm 0.7 \mathrm{kyrcalBP}$ and $29.8 \pm 1.4 \mathrm{kyrcalBP})$ than the corresponding OSL ages $(26.6 \pm 3.1 \mathrm{kyr}, 32.0 \pm 3.5 \mathrm{kyr}$ and $45.6 \pm 5.3 \mathrm{kyr})$. This finding suggests that a post-sedimentary $n$-alkane contamination presumably by roots has 15 occurred.

In order to estimate the post-sedimentary $n$-alkane contamination more quantitatively, we applied a ${ }^{14} \mathrm{C}$ mass balance calculation based on the measured pMC (percent modern carbon) values, the calculated syn-sedimentary pMC values and $\mathrm{pMC}$ values suspected to reflect likely time points of post-sedimentary contamination (current, modern, $3 \mathrm{kyr}, 6 \mathrm{kyr}$ and $9 \mathrm{kyr}$ ). Accordingly, current and modern root-contamination would account for up to $7 \%$, a $3 \mathrm{kyr}$ old root-contamination for up to $10 \%$, and an Early and Middle Holocene root-contamination for up to $20 \%$ of the total sedimentary $n$-alkane pool.

We acknowledge and encourage that these first radiocarbon results need further e.g. carboxylic acids or alcohols as further lipid biomarkers.

BGD

9, 9875-9896, 2012

\section{n-Alkane lipid biomarkers in loess}

M. Zech et al.

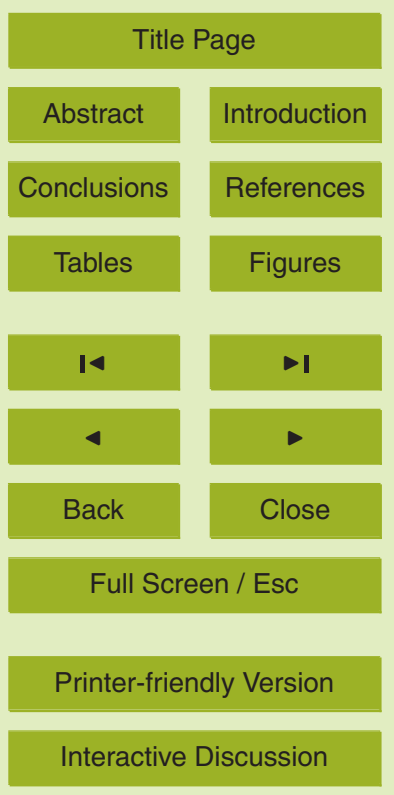




\section{Introduction}

Loess-paleosol sequences (LPSs) are important terrestrial archives for reconstructing Quaternary climate and landscape history (Frechen, 2011; Markovic et al., 2011; Zöller and Faust, 2009). Although biomarkers (also called molecular fossils) have been 5 proven for decades to be of outstanding value in marine and lacustrine sediments (Eglinton and Eglinton, 2008), they are investigated in LPSs only relatively recently (M. Zech et al., 2011b). This has several reasons, amongst others the generally very low concentration of organic matter in loess. Yet, one famous application is the use of amino acid racemisation for establishing geochronologies (Novothny et al., 2009; Oches and McCoy, 2001; M. Zech et al., 2008).

During the last decade, additionally plant leaf wax derived lipids, namely $n$-alkanes came into the focus of organic geochemists focussing on loess research (Bai et al., 2009; Xie et al., 2003; Zhang et al., 2006). This can be partly attributed to the relatively easy lipid extraction procedure, which allows obtaining results even from very organicpoor loess samples. On the one hand, $n$-alkanes are used to infer vegetations changes in terms of grasses (dominated by the alkane homologues $n-\mathrm{C}_{31}$ and $n-\mathrm{C}_{33}$ ) versus trees (dominated by the alkane homologues $n-\mathrm{C}_{27}$ and $n-\mathrm{C}_{29}$ ). Only very recently, it was highlighted that a correction procedure for degradation is indispensable to avoid misinterpretations (Buggle et al., 2010; M. Zech et al., 2009, 2012a). On the other hand, the compound-specific deuterium/hydrogen $(\mathrm{D} / \mathrm{H})$ ratio of $n$-alkanes is used to infer paleoclimatic information (Liu and Huang, 2005; R. Zech et al., 2011).

A major and crucial assumption of all studies focussing on $n$-alkanes, as well as on any other biomarker in loess, is that the $n$-alkanes are deposited syn-sedimentary and are not contaminated significantly by post-sedimentary processes. While this seems not to hold true for certain biomarkers, e.g. because of subsurface production of archaea- and bacteria-derived membrane lipids (GDGTs = glycerol dialkyl glycerol tetraethers) called "growth depth effect" (R. Zech et al., 2012), post-sedimentary $n$-alkane contamination in loess is still highly disputed. Given that $n$-alkanes are
BGD

9, 9875-9896, 2012

\section{n-Alkane lipid biomarkers in loess}

M. Zech et al.

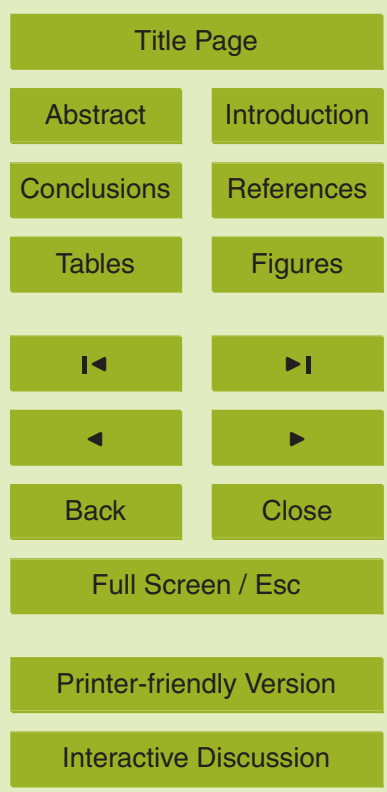


hydrophobic, they are not dissolved in and leached by soil water. Furthermore, the admittedly still very scarce data about $n$-alkane concentrations in roots point to much lower concentrations compared to leaves (Huang et al., 2011; M. Zech et al., 2012b). However, it was highlighted recently, that a significant soil microbial contribution dur5 ing early litter degradation does not only occur for short- and middle-, but also for the long-chain $n$-alkanes (Nguyen Tu et al., 2011; M. Zech et al., 2011). Last but not least, Andersson et al. (2011) showed that the contribution of $n$-alkanes from rootlets has to be considered in peat sequences, and studying rhizolith organic matter (OM) in loess, Gocke et al. $(2010,2011)$ conclude that overprinting of loess OM even in loess dis10 tant to former roots cannot be excluded. While ${ }^{14} \mathrm{C}$-dating of the $n$-alkane fraction has already been proven to be a powerful tool in soil science and sea sediments (Huang et al., 1996; Kusch et al., 2010; Lichtfouse and Eglinton, 1995), according to our knowledge ${ }^{14} \mathrm{C}$-dating of alkanes is not yet applied in loess research.

The aim of this study is to evaluate the potential of $n$-alkane-specific ${ }^{14} \mathrm{C}$-dating for answering the question whether $n$-alkane biomarkers in loess are of syn-sedimentary of post-sedimentary age. Here we present for the first time a comparison of $n$ alkane ${ }^{14} \mathrm{C}$-ages with sedimentation ages obtained by optically stimulated luminescence (OSL) dating. This approach allows quantitatively estimating the amount of postsedimentary contamination and therefore helping to shed light on the crucial question

\section{Material and methods}

\subsection{The Gleina loess-paleosol sequence}

Loess and paleosol samples were collected from the Gleina loess-paleosol sequence $\left(51^{\circ} 13^{\prime} 58^{\prime \prime} \mathrm{N}, 13^{\circ} 14^{\prime} 39^{\prime \prime} \mathrm{E}\right)$, which is located in the Saxonian Loess Region, Eastern Germany. A detailed description of the stratigraphy was provided previously by Meszner et al. (2011). In brief, the uppermost meter is built up of decalcified material

\section{BGD}

9, 9875-9896, 2012

\section{n-Alkane lipid biomarkers in loess}

M. Zech et al.

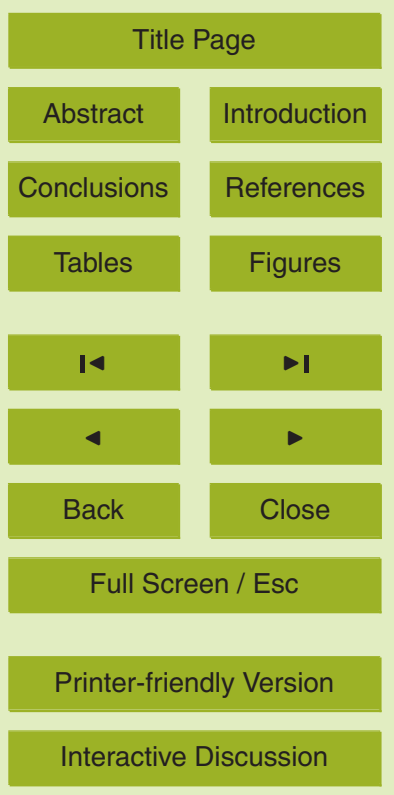

Interactive Discussion 
representing the Holocene pedogenetic impact. Major parts of the Holocene soil (presumably a Luvisol) are truncated and a plough horizon (Ap-horizon) nowadays forms the topsoil. Below, down to approximately $8 \mathrm{~m}$ depth, six paleosols, which can be described as gelic Gleysols and brown tundra Gleysols, alternate with loess layers 5 (Fig. 1a). From approximately $8 \mathrm{~m}$ on, there is strong evidence for accumulation of partly reworked material. In situ pedogenesis contributed to the formation of a gelic Gleysol in approximately $8.5 \mathrm{~m}$ depth and to the formation of the decalcified so-called "Gleina complex" in approximately $10 \mathrm{~m}$ depth. The underlying so-called "Lommatzsch Complex" was sampled from a nearby profile (approximately $20 \mathrm{~m}$ ) and is separated in 10 the sketch by an unconformity.

Modern root contamination partly occurred in the upper $4.5 \mathrm{~m}$ of the sequence, whereas hardly any modern roots were found in the lower part of the sequence. The risk of a modern lateral root contamination was minimised by setting back the exposure wall by at least half a meter over the whole height of the exposure. Some few rhizoliths, 15 possibly documenting a Holocene root contamination were found in the gelic gleysol in $2 \mathrm{~m}$ depth.

\section{$2.2 n$-Alkane preparation, radiocarbon dating and percentage estimation of post-sedimentary $n$-alkane contamination by roots}

For radiocarbon dating of the $n$-alkane fraction, four samples were selected from the 20 Gleina loess-paleosol sequence based on the $n$-alkane concentrations published by M. Zech et al. (2012a) (Fig. 1). Additionally, four presumably 160 kyr old samples from a NE-Siberian permafrost paleosols sequence (M. Zech et al., 2010) were analysed as blanks (Table 1).

The $n$-alkane preparation followed mainly the procedure described by Zech and 25 Glaser (2008), however being adopted by using Soxhlet extraction (methanol/toluene, $7 / 3$ ) and glass fibre extraction thimbles, which were pre-heated to $300^{\circ} \mathrm{C}$ for several hours. After saponification of the total lipid extract by heating with sodium hydroxide $(\mathrm{NaOH}, 0.5 \mathrm{M}$ in methanol) the $n$-alkane fraction was solvent-extracted with hexane 9880

\section{BGD}

9, 9875-9896, 2012

\section{n-Alkane lipid biomarkers in loess}

M. Zech et al.

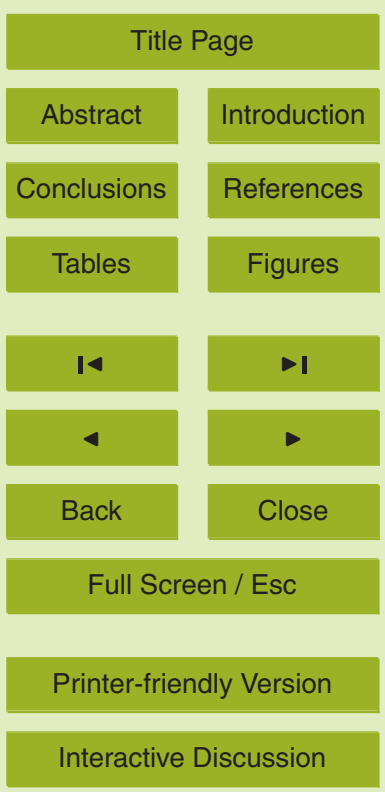


$(2 \times 3 \mathrm{ml})$ and purified over silica/aluminium oxide (each $3 \mathrm{~g}$ and $5 \%$ deactivated) columns, from which they were eluted with hexane/toluene (85/15). The $n$-alkane patterns and relative abundance of the $n$-alkanes were determined by gas chromatography (HP 6890) using a flame ionisation detector (chromatograms are shown in Fig. 1).

$5 \quad$ For radiocarbon analysis, the $n$-alkane fractions (500 to $2000 \mu \mathrm{g}$ ) in the GC-vials were dried up, redissolved in dichloromethane (DCM) and transferred to quartz combustion tubes in the Poznan Radiocarbon Laboratory, Poland. After drying out DCM, the samples were washed with ethanol; the ethanol was sucked out with a pipette and dried out. Finally, the samples were washed with water; again, water was sucked out 10 with a pipette and the samples were dried out. Tests with fossil coal showed that only this procedure ensured the quantitative removal of solvent-derived carbon (Table 1).

The two blank samples from Siberia, which were treated with the washing procedure described above, yielded pMC (percent modern carbon) values of 2.53 and 2.27, respectively (Table 1 ). Given that this is clearly above the normally measured back15 ground values of $0.3 \pm 0.1 \mathrm{pMC}$, we suppose that this has to be attributed to a slight but seemingly reproducible ${ }^{14} \mathrm{C}$ contamination during $n$-alkane extraction and preparation. By contrast, we exclude a modern in-situ contamination for the Siberian soil samples because of permafrost conditions. Hence, we performed a background correction for sample pMC values assuming a $2.4 \pm 0.8 \%$ contamination with modern carbon $(\sim 100 \mathrm{pMC})$. Calibration of the ${ }^{14} \mathrm{C}$ ages was done with quickcal2007 vers. 1.5 (Danzeglocke et al., 2012).

Given that furthermore three of the $n$-alkane samples yielded calibrated ${ }^{14} \mathrm{C}$ ages being clearly younger than the respective sedimentation ages as assessed by OSL dating (Fig. 1), we estimated for these samples the syn-sedimentary pMC values based on the (partly interpolated) OSL ages according to the equation

$\mathrm{pMC}_{\text {syn-sedimentary }}=100 \times\left(\frac{1}{2}\right)^{\frac{t}{\tau \frac{1}{2}}}$,

\section{BGD}

9, 9875-9896, 2012

\section{n-Alkane lipid biomarkers in loess}

M. Zech et al.

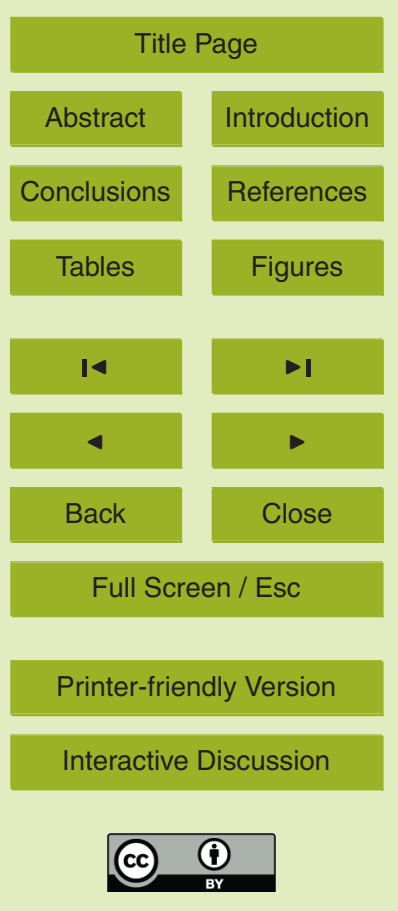


where 100 represents the modern ${ }^{14} \mathrm{C}$ value, i.e. $100 \mathrm{pMC}, t$ is the estimated uncalibrated ${ }^{14} \mathrm{C}$ age (assuming that $\mathrm{OSL}$ age $=$ calibrated ${ }^{14} \mathrm{C}$ age and using quickcal2007 vers.1.4, Danzeglocke et al., 2012) and $T \frac{1}{2}$ is the so-called Libby's half-life time of radiocarbon $(5.568 \mathrm{kyr})$. Using the same equation we also estimated the $\mathrm{pMC}_{\text {post-sedimentary }}$ 5 values for suspected Holocene times of post-sedimentary $n$-alkane contamination by roots (3, 6 and $9 \mathrm{kyr}$, respectively; Table 2$)$.

The percentage of post-sedimentary $n$-alkane contamination " $x$ " was then estimated using a ${ }^{14} \mathrm{C}$ mass balance calculation according to the equation

$x \%=\frac{\mathrm{pMC}_{\text {measured }}-\mathrm{pMC}_{\text {syn-sedimentary }}}{\mathrm{pMC}_{\text {post-sedimentary }}-\mathrm{pMC}_{\text {syn-sedimentary }}}$.

\subsection{Optically stimulated luminescence (OSL) dating}

A numerical chronostratigraphy of the section Gleina was established by OSL dating using fine grain $(4-11 \mu \mathrm{m})$ quartz separates. Therefore eight luminescence samples were taken during nighttime and prepared in the laboratory for equivalent dose $\left(D_{\mathrm{e}}\right)$ determination using standard methods for fine grain quartz dating (Fuchs et al., 2005).

15 The OSL measurements were carried out on a Risø TL/OSL DA-15 readers in the UV band $(340 \Delta 80 \mathrm{~nm})$ using blue stimulation $(470 \Delta 30 \mathrm{~nm})$. For $D_{\mathrm{e}}$ determination on 12 aliquots per sample a standard single aliquot regenerative (SAR) protocol according to Murray and Wintle (2000) was applied using the first $0.2 \mathrm{~s}$ after subtracting the background from the last $8 \mathrm{~s}$ of the shine-down curves. The protocol parameters were previously deduced from test measurements. The purity of the quartz extracts was tested by infrared light (IR) stimulation. The mean $D_{\mathrm{e}}$ and the standard error for each sample were used for age calculation. For dose rate calculation the $U$, Th and $K$ concentration were measured using ICP-MS (K) and thick source alpha-counting (e.g. Zöller and Pernicka, 1989). The $\alpha$-effectiveness (a-value) was measured following the procedure described in Mauz et al. (2006) and Lai et al. (2008). The cosmic dose rate was calculated according to Prescott and Hutton (1994). A water content of $20 \pm 5 \%$

BGD

9, 9875-9896, 2012

\section{n-Alkane lipid biomarkers in loess}

M. Zech et al.

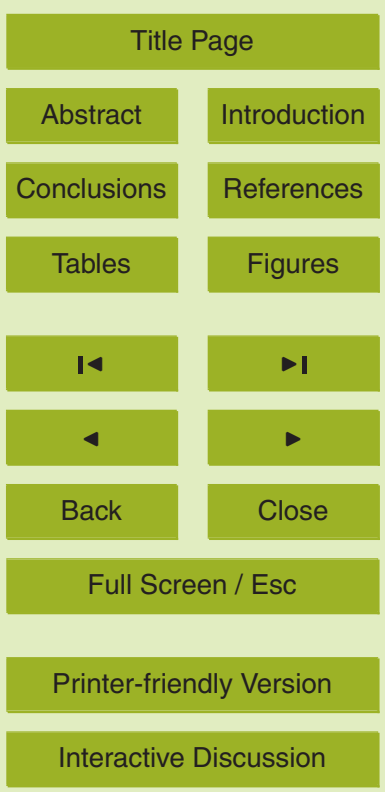


was used. Further methodological details on the luminescence dating are given in the Supplement.

\section{Results and discussion}

\section{1 $n$-Alkane patterns and ${ }^{14} \mathrm{C}$ ages of the $n$-alkane fractions}

5 The $n$-alkane patterns of the four ${ }^{14} \mathrm{C}$-dated $n$-alkane fractions reveal three noteworthy features (Fig. 1). First, the long-chain $n$-alkanes $\left(>n-\mathrm{C}_{25}\right)$ are characterised by high odd-over-even predominances (OEP), i.e. particularly the $n$-alkanes $n-\mathrm{C}_{27}, n-\mathrm{C}_{29}, n$ $\mathrm{C}_{31}$ and $n-\mathrm{C}_{33}$ are by far more abundant than the $n$-alkanes $n-\mathrm{C}_{28}, n-\mathrm{C}_{30}$ and $n-\mathrm{C}_{32}$. Such patterns are typical for plant leaf wax derived $n$-alkanes (Eglington and Hamilton, 101967 ; Kolattukudy, 1976) and the dominance of $n-C_{31}$ furthermore indicates an prevailing origin from grasses (M. Zech et al., 2012a). Second, also $n-\mathrm{C}_{18}$ and $n-\mathrm{C}_{20}$ occur in relatively high amounts; in sample 15 additionally $n-C_{21}$ and $n-C_{22}$ (Fig. 1). While these $n$-alkanes typically do not occur in higher plant leaf waxes or at least in very low concentrations, Wiesenberg et al. (2009) showed that charring of grass biomass at

400 to $500^{\circ} \mathrm{C}$ produces exactly such $n$-alkane patterns. We hence conclude that apart from plant leaf waxes $\left(>n-\mathrm{C}_{25}\right)$, also charred biomass contributed significantly to the investigated $n$-alkane fractions with $n-C_{18}$ and $n-C_{20}$ serving as respective molecular markers. Third, although to a different degree, the baselines from $\sim 15$ to $23 \mathrm{~min}$ in the chromatograms are elevated. Such humps are called unresolved complex mixture (UCM) and are often observed in GC-chromatograms of petroleum (Frysinger et al., 2003). In soil and paleosols where a petroleum contamination can be excluded, increased UCM humps may indicate soil OM degradation (M. Zech et al., 2012a) and/or biomass burning. Indeed, Eckmeier and Wiesenberg (2009) reported that UCM humps are present in Mesolithic and Neolithic pit fillings containing charred organic matter or black carbon and UCM humps are also formed in the charring experiments of Wiesenberg et al. (2009).
BGD

9, 9875-9896, 2012

\section{n-Alkane lipid biomarkers in loess}

M. Zech et al.

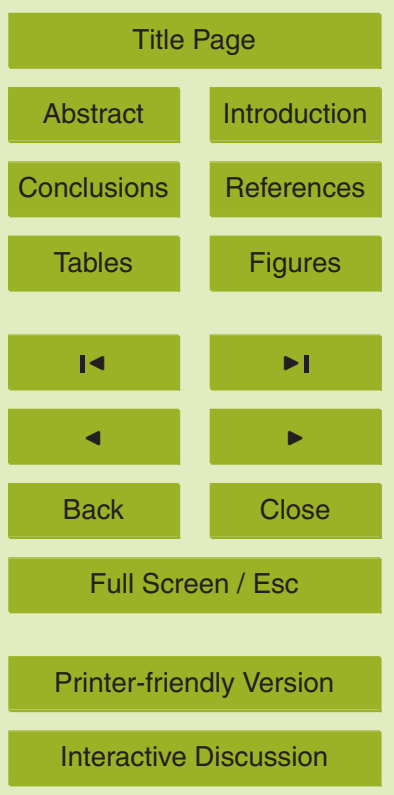


The radiocarbon dating of the $n$-alkane fractions of the four investigated samples yielded background and $\delta^{13} \mathrm{C}$-corrected ${ }^{14} \mathrm{C}$ ages ranging from $20.3 \pm 0.7 \mathrm{kyrcalBP}$ for the uppermost sample 15 to $29.8 \pm 1.4$ kyrcalBP for the lowermost sample 23 (Table 1 and Fig. 1). A striking chronostratigraphic inconsistency characterises the second uppermost sample 19 being dated to $29.1 \pm 1.4$ kyrcalBP and the subjacent sample 21 being dated to $22.1 \pm 0.8 \mathrm{kyrcalBP}$ (Fig. 1). In this context, it is noteworthy, that below $7.8 \mathrm{~m}$ depth, the loess-paleosol sequence of Gleina is partly affected by deposition of reworked, older soil material. On the one hand, this could result in "too old" radiocarbon ages for the dated $n$-alkane fractions provided that the reworked soil material 10 contained significant amounts of $n$-alkanes. Yet, M. Zech et al. (2012b) found that particularly the Eemian soil horizons of both the Gleina and the Nussloch (W-Germany) loess-paleosols sequences are characterised by extremely low $n$-alkane concentrations. On the other hand, deposition of reworked sediments may have implications for the interpretation of luminescence data when reconstructing the sedimentation history 15 of loess-paleosol sequences due to insufficient signal resetting, which may cause discrepancies between the ${ }^{14} \mathrm{C}$ - and OSL-derived ages.

\subsection{OSL ages and establishment of a chronostratigraphy for the Gleina LPS}

OSL fine grain quartz ages and their $D_{\mathrm{e}}$ values are shown in Table 3 and Fig. 1. Age results are given as mean and $2-\sigma$ error. All age values consistently increase with 20 profile depth and within errors no age inversion occurred. The quartz luminescence signals were almost bright, fast decaying and highly reproducible during determined preheat and dose recovery tests. For all samples no significant feldspar contamination (IRSL/OSL $<1 \%$ ) was detected. Consequently, the derived $D_{\mathrm{e}}$ distributions show a narrow scatter $\left(c_{v}\right.$ ca. $5 \%$ ). The dose rate (Supplement) varies between $3.1 \pm 0.2 \mathrm{~Gy} \mathrm{kyr}^{-1}$ 25 (BT836) and $3.5 \pm 0.2 \mathrm{~Gy} \mathrm{kyr}^{-1}$ (BT842) showing values typical for loess (e.g. Kreutzer et al., 2012).

\section{BGD}

9, 9875-9896, 2012

\section{n-Alkane lipid biomarkers in loess}

M. Zech et al.

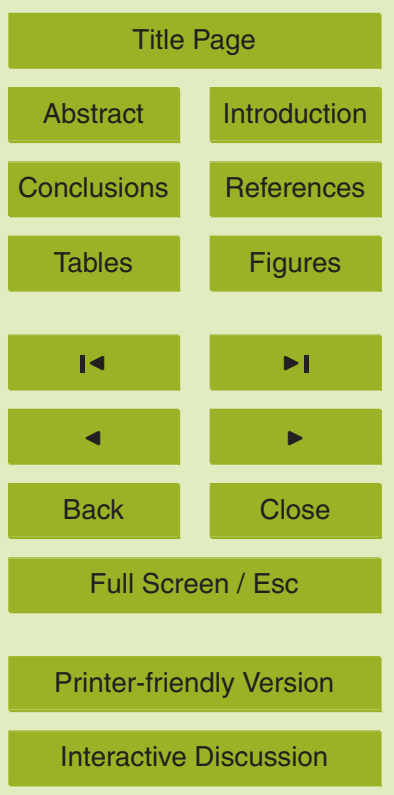


For the uppermost part of the profile (ca. $3 \mathrm{~m}$ up to ca. $8 \mathrm{~m}$ ) ages between $24.5 \pm 2.7 \mathrm{kyr}$ (BT835) and 26.6 $\pm 2.9 \mathrm{kyr}$ (BT839) indicating a rapid aeolian deposition during the presumed Last Glacial Maximum (MIS2, Lisiecki and Raymo, 2005). These results are in accordance with previous findings from the Saxonian Loess Region 5 (Kreutzer et al., 2012; Meszner et al., 2011, 2012). The onset of loess sedimentation at ca. $10 \mathrm{~m}$ was attributed to the MIS3 (BT842: $45.6 \pm 5.3 \mathrm{kyr}$, BT840: $39.0 \pm 4.4 \mathrm{kyr}$ ). Below a hiatus at ca. $10.2 \mathrm{~m}$ the sediment was dated as early Weichselian $(72.8 \pm 8.1 \mathrm{kyr}$ BT844, MIS5a to MIS4). This hiatus has been observed for all investigated loess profiles in the Saxonian Loess Region so far. In contrast to other investigated loess profiles 10 in Saxony (Ostrau, Seilitz: Kreutzer et al., 2012; Meszner et al., 2012), where the onset of loess sedimentation has been dated at ca. $30 \mathrm{kyr}$ (transition MIS3 to MIS2), for the Gleina loess the OSL ages reveal an onset of loess deposition in the early MIS3. These findings may indicate locally limited loess preservation due a special morphographic position. However, an age overestimation due to an incomplete signal resetting 15 during secondary translocation processes cannot be fully excluded, since it is not possible to detect any incomplete signal resetting using fine grain quartz dating. Therefore, finally the reasons for the observed discrepancy remain unknown. Further details on the luminescence dating results are provided in the Supplement.

\subsection{Comparison - towards a quantification of post-sedimentary $n$-alkane contamination}

The comparison of the ${ }^{14} \mathrm{C}$ ages with the OSL ages (Fig. 1) shows that within the errors the $n$-alkane fraction of sample 19 reveals the same age $(29.2 \pm 1.4 \mathrm{kyrcalBP})$ as the two surrounding OSL samples BT838 and BT839 (mean age 27.3 $\pm 3.0 \mathrm{kyr}$ ). By contrast, the three other $n$-alkane samples are clearly younger $(20.3 \pm 0.7 \mathrm{kyr}$ calBP, 25

$22.1 \pm 0.7 \mathrm{kyrcalBP}$ and $29.8 \pm 1.4 \mathrm{kyrcalBP}$ ) than the corresponding OSL ages (BT837: $26.5 \pm 3.1 \mathrm{kyr}$, interpolated: $32.0 \pm 3.5 \mathrm{kyr}$ and BT842: $45.6 \pm 5.3 \mathrm{kyr}$, respectively). Assuming that all OSL ages reflect sedimentation ages and are not affected significantly by insufficient bleaching (see discussion above), this finding suggests

\section{BGD}

9, 9875-9896, 2012

\section{n-Alkane lipid biomarkers in loess}

M. Zech et al.

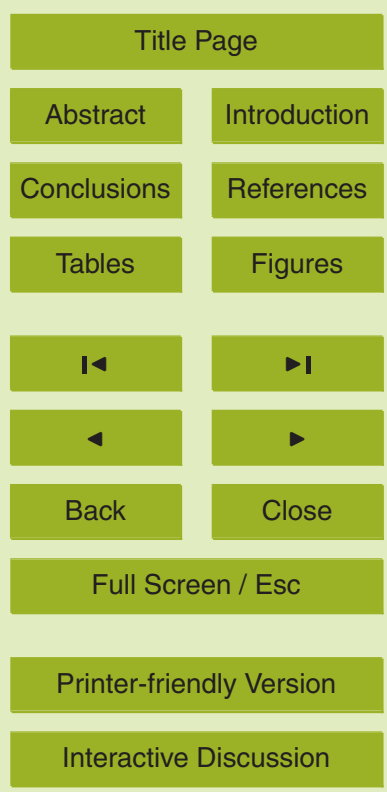


that one $n$-alkane sample (sample 19) has a syn-sedimentary age, whereas a postsedimentary $n$-alkane contamination presumably by roots made the three other $n$ alkane samples younger.

In order to estimate the post-sedimentary $n$-alkane contamination more quantita5 tively, we calculated the theoretical syn-sedimentary pMC values according to Eq. (1) using the OSL ages as sedimentation ages (Table 2). Furthermore, we suspected on the one hand a current ( $100 \mathrm{pMC}$ ) or modern (last decades) $n$-alkane contamination by roots. Given that Levin et al. (1985) observed atmospheric pMC values of more than 120 from 1962 to 1985 (up to almost 200 pMC in the year 1963 due to nuclear weapon 10 tests) in the Northern Hemisphere, we used a pMC value of 120 as representing modern contamination. On the other hand, we suspected a Holocene root-contamination and calculated according to Eq. (1) the theoretical pMC values for three Holocene time points (3, 6 and $9 \mathrm{kyr}$, see Table 2). This is based on the finding of Gocke et al. (2010) and Pustovoytov and Terhorst (2004) that rhizoliths in last-glacial loess are of Holocene

age. Using the measured and the calculated syn-sedimentary and post-sedimentary pMC values the percentages of post-sedimentary $n$-alkane contamination for the different contamination scenarios were then estimated by applying a ${ }^{14} \mathrm{C}$ mass balance calculation (Eq. 2). Accordingly, a current and modern root-contamination would account for up to $7 \%$ in the samples 15 and 21 and for up to $4 \%$ in the lowermost sample 23. When assuming a $3 \mathrm{kyr}$ old contamination the amount of post-sedimentary $n$-alkanes in the samples 15, 21 and 23 increases to $9 \%, 10 \%$ and $5 \%$, respectively. In the most progressive assumption, Early and Middle Holocene roots would have accounted for up to $19 \%, 20 \%$ and $11 \%$ (sample 15, 21 and 23 , respectively) of the post-sedimentary $n$-alkane contamination.

25 Given that especially the luminescence data have relatively large errors $(\geq 3 \mathrm{kyr}$, see Table 2), we performed the ${ }^{14} \mathrm{C}$ mass balance calculation also for the extreme values, which were calculated by subtracting and adding the 2-sigma uncertainty of the mean OSL ages. According to the thus determined error ranges (Table 2), the calculated percentages of root-contamination are rather robust for the current, modern and $3 \mathrm{kyr}$

\section{BGD}

9, 9875-9896, 2012

\section{n-Alkane lipid biomarkers in loess}

M. Zech et al.

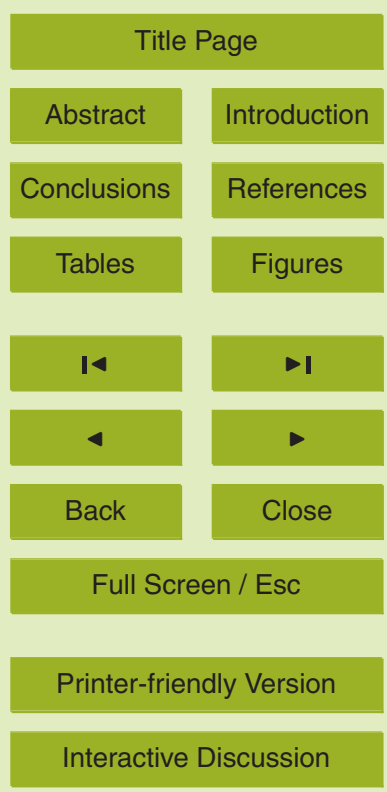

9886 
contamination scenarios. By contrast, the error ranges are considerably higher for the $6 \mathrm{kyr}$ and $9 \mathrm{kyr}$ contamination scenarios (up to 16-23\%, sample 21, $9 \mathrm{kyr}$ scenario, Table 2). An extension of the above presented approach using a ${ }^{14} \mathrm{C}$ mass calculation based on more data is therefore inevitably needed to confirm the extent of contamina5 tion as derived from our first results.

\section{Conclusions}

In this study, the $n$-alkane fraction of lipid extracts from a loess-paleosol sequence (LPS Gleina) was dated for the first time. The calibrated ${ }^{14} \mathrm{C}$ ages of the lipid biomarkers and the comparison with sedimentation ages as assessed by OSL dating suggest that three 10 of four samples experienced a post-sedimentary $n$-alkane contamination presumably by roots. Using a ${ }^{14} \mathrm{C}$ mass balance calculation the post-sedimentary contamination can be estimated. Accordingly, the extent of contamination strongly depends on the contamination scenario, i.e. it ranges from $0 \%$ to $7 \%$ for current and modern contamination, whereas it ranges from $0 \%$ to $20 \%$ for 9 kyr old contamination. There is 15 no evidence for an overall overprinting of sedimentary $n$-alkane patters and we hence confirm the value of $n$-alkanes as plant-derived biomarkers in loess. Nevertheless, our finding also highlights that more radiocarbon dating is needed for rhizoliths in loess (time of root-contamination) in order to assess the question "syn-sedimentary or postsedimentary?" more quantitatively.

20 Furthermore, we acknowledge and encourage that our first radiocarbon results need further confirmation both from other localities and for different biomarkers, e.g. carboxylic acids or alcohols as further lipid biomarkers. While lipid biomarkers have the great advantage that they can be easily extracted even from very organic-poor loess, we explicitly suggest that $n$-alkanes may not be representative biomarkers for assessable in water and occur in comparatively low amounts in roots.

\section{BGD}

9, 9875-9896, 2012

\section{n-Alkane lipid biomarkers in loess}

M. Zech et al.

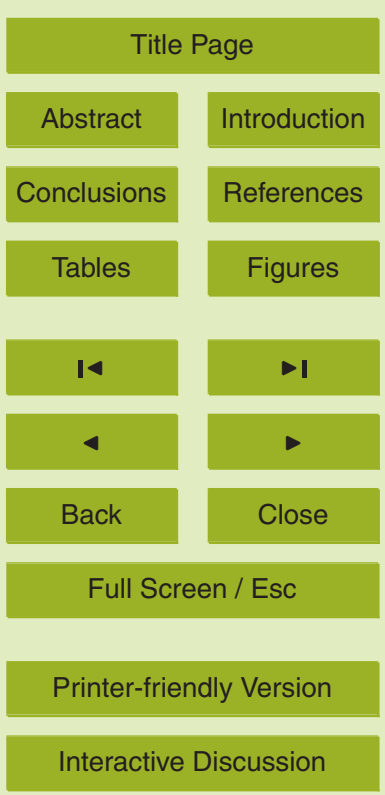




\section{Supplementary material related to this article is available online at: http://www.biogeosciences-discuss.net/9/9875/2012/ bgd-9-9875-2012-supplement.pdf.}

Acknowledgements. We are very grateful for constructive discussions and comments from 5 E. Eckmeier, M. Gocke, E. Lehndorff, J. Rethemeyer and G. Wiesenberg. B. Huwe and L. Zöller generously provided laboratory facilities and A. Mergner and M. Sroka supported us technically during laboratory work. Furthermore we thank $A$. Kadereit from the Luminescence Laboratory of Heidelberg for her cooperation and making more machine time available. This study was funded by the German Research Foundation (DFG; FA 239/13-2 and DFG; ZE 844/1-1). The

10 work of S. Kreutzer and M. Fuchs was gratefully funded by the DFG (FU 417/7-2). M. Zech also greatly acknowledges the support provided by the Alexander von Humboldt-Foundation.

\section{References}

Andersson, R., Kuhry, P., Meyers, P., Zebühr, Y., Crill, P., and Mörth, M.: Impacts of paleohydrological changes on $n$-alkane biomarker compositions of a Holocene peat sequence in the 15 Eastern European Russian Arctic, Org. Geochem., 42, 1065-1075, 2011.

Bai, Y., Fang, X., Nie, J., Wang, Y., and Wu, F.: A preliminary reconstruction of the paleoecological and paleoclimatic history of the Chinese Loess Plateau from the application of biomarkers, Palaeogeogr. Palaeoclim. Palaeoecol., 271, 161-169, 2009.

Buggle, B., Wiesenberg, G., and Glaser, B.: Is there a possibility to correct fossil $n$-alkane data for postsedimentary alteration effects?, Appl. Geochem., 25, 947-957, 2010.

Danzeglocke, U., Jöris, O., and Weninger, B.: CalPal-2007online, available at: http://www. calpal.online/ (last access: July 2012), 2012.

Eckmeier, E. and Wiesenberg, G.: Short-chain $n$-alkanes (C16-20) in ancient soil are useful molecular markers for prehistoric biomass burning, J. Archaeol. Sci., 36, 1590-1596, 2009.

25 Eglington, G. and Hamilton, R.: Leaf epicuticular waxes, Science, 156, 1322-1334, 1967.

Eglinton, T. and Eglinton, G.: Molecular proxies for paleoclimatology, Earth Planet. Sc. Lett., 275, 1-16, 2008.

Frechen, M.: Loess in Eurasia, special issue in: Quat. Int., 234, 1-202, 2011.

\section{BGD}

9, 9875-9896, 2012

\section{n-Alkane lipid biomarkers in loess}

M. Zech et al.

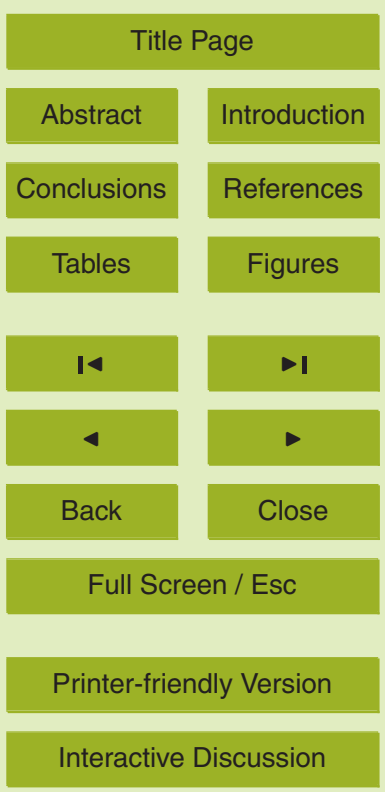


Frysinger, G., Gaines, R., Xu, L., and Reddy, C.: Resolving the unresolved complex mixture in petrolium-contaminated sediments, Environ. Sci. Technol., 37, 1653-1662, 2003.

Fuchs, M., Straub, J., and Zöller, L.: Residual luminescence signals of recent river flood sediments: a comparison between quartz and feldspar of fine- and coarse-grain sediments, Ancient TL, 23, 25-30, 2005.

Gocke, M., Kuzyakov, Y., and Wiesenberg, G.: Rhizoliths in loess - evidence for postsedimentary incorporation of root-derived organic matter in terrestrial sediments as assessed from molecular proxies, Org. Geochem., 41, 1198-1206, 2010.

Gocke, M., Kuzyakov, Y., and Wiesenberg, G.: Differentiation of plant derived organic matter in soil, loess and rhizoliths based on $n$-alkane molecular proxies, Biogeochemistry, doi:10.1007/s10533-011-9659-y, 2011.

Huang, X., Wang, C., Zhang, J., Wiesenberg, G., Zhang, Z., and Xie, S.: Comparison of free lipid compositions between roots and leaves of plants in the Dajiuhu Peatland, Central China, Geochem. J., 45, 365-373, 2011.

15 Huang, Y., Bol, R., Harkness, D. D., Ineson, P., and Eglington, G.: Post-glacial variations in distributions, ${ }^{13} \mathrm{C}$ and ${ }^{14} \mathrm{C}$ contents of aliphatic hydrocarbons and bulk organic matter in three types of British acid upland soils, Org. Geochem., 24, 273-287, 1996.

Kolattukudy, P. E. (ed.): Biochemistry of plant waxes, in: Chemistry and Biochemistry of Natural Waxes, Elsevier, Amsterdam, 290-349, 1976.

20 Kreutzer, S., Fuchs, M., Meszner, S., and Faust, D.: OSL chronostratigraphy of a loesspalaeosol sequence in Saxony/Germany using quartz of different grain sizes, Quat. Geochronol., 10, 102-109, doi:10.1016/j.quageo.2012.01.004, 2012.

Kusch, S., Rethemeyer, J., Schefuß, E., and Mollenhauer, G.: Controls on the age of vascular plant biomarkers in Black Sea sediments, Geochim. Cosmochim. Acta, 74, 7031-7047, 252010.

Lai, Z., Zöller, L., Fuchs, M., and Brückner, H.: Alpha efficiency determination for OSL of quartz extracted from Chinese loess, Radiat. Meas., 43, 767-770, 2008.

Levin, I., Kromer, B., Schoch-Fischer, H., Bruns, M., Münnich, M., Berdau, D., Vogel, J. C., and Münnich, K. O.: 25 Years of tropospheric ${ }^{14} \mathrm{C}$ observations in Central Europe, Radiocarbon, 27, 1-19, 1985.

Lichtfouse, E. and Eglinton, T.: ${ }^{13} \mathrm{C}$ and ${ }^{14} \mathrm{C}$ evidence of pollution of a soil by fossil fuel and reconstruction of the composition of the pollutant, Org. Geochem., 23, 969-973, 1995. 
Lisiecki, L. E. and Raymo, M. E.: A Pliocene-Pleistocene stack of 57 globally distributed benthic $\delta^{18} \mathrm{O}$ records, Paleoceanography, 20, PA1003, doi:10.1029/2004PA001071, 2005.

Liu, W. and Huang, Y.: Compound specific D/H ratios and molecular distributions of higher plant leaf waxes as novel paleoenvironmental indicators in the Chinese Loess Plateau, Org.

5 Geochem., 36, 851-860, 2005.

Markovic, S., Catto, N., Smalley, I., and Zöller, L.: The second Loessfest (2009), special issue in: Quat. Int., 240, 1-192, 2011.

Mauz, B., Packman, S. C., and Lang, A.: The alpha effectiveness in silt-sized quartz: new data obtained by single and multiple aliquot protocols, Ancient TL, 24, 47-52, 2006.

10 Meszner, S., Fuchs, M., and Faust, D.: Loess-Palaeosol-sequences from the loess area of Saxony (Germany), Eiszeitalter und Gegenwart - Quat. Sci. J., 60, 47-65, 2011.

Meszner, S., Kreutzer, S., Faust, D., and Fuchs, M.: Late Pleistocene landscape evolution dynamics in Saxony/Germany - palaeoenvironemental reconstruction on loess-palaeosol sequences, Quat. Int., submitted, 2012.

Murray, A. S. and Wintle, A. G.: Luminescence dating of quartz using an improved single-aliquot regenerative-dose protocol, Radiat. Meas., 32, 57-73, 2000.

Nguyen Tu, T., Egasse, C., Zeller, B., Bardoux, G., Biron, P., Ponge, J., David, B., and Derenne, S.: Early degradation of plant alkanes in soils: a litterbag experiment using ${ }^{13} \mathrm{C}$ labeled leaves, Soil Biol. Biochem., 43, 2222-2228, 2011.

20 Novothny, A., Frechen, M., Horváth, E., Bradák, B., Oches, E., McCoy, W., and Stevens, T.: Luminescence and amino acid racemization chronology of the loess-paleosol sequence at Süttő, Hungary, Quat. Int., 198, 62-76, 2009.

Oches, E. and McCoy, W.: Historical developments and recent advances in amino acid geochronology applied to loess research: examples from North America, Europe, and China,

25 Earth-Sci. Rev., 54, 173-192, 2001.

Prescott, J. R. and Hutton, J. T.: Cosmic ray contributions to dose rates for luminescence and ESR dating: large depths and long-term time variations, Radiat. Meas., 23, 497-500, 1994.

Pustovoytov, K. and Terhorst, B.: An isotopic study of a Late Quaternary loess-paleosol sequence in SW Germany, Rev. Mexic. Cie. Geológ., 21, 88-93, 2004.

Wiesenberg, G., Lehndorff, E., and Schwark, L.: Thermal degradation of rye and maize straw: lipid pattern changes as a function of temperature, Org. Geochem., 40, 167-174, 2009.

Xie, S., Chen, F., Wang, Z., Wang, H., Gu, Y., and Huang, Y.: Lipid distributions in loess-paleosol sequences from northwest China, Org. Geochem., 34, 1071-1079, 2003.

BGD

9, 9875-9896, 2012

\section{n-Alkane lipid biomarkers in loess}

M. Zech et al.

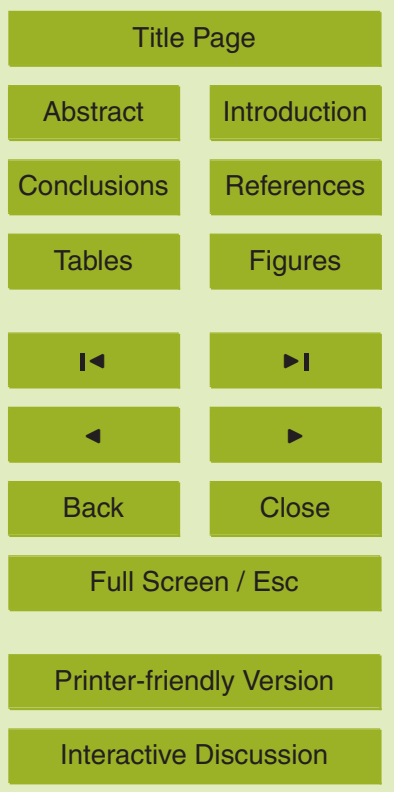

9890 
Zech, M. and Glaser, B.: Improved compound-specific $\delta^{13} \mathrm{C}$ analysis of $n$-alkanes for application in palaeoenvironmental studies, Rapid Commun. Mass Spectr., 22, 135-142, 2008.

Zech, M., Zech, R., Zech, W., Glaser, B., Brodowski, S., and Amelung, W.: Characterisation and palaeoclimate of a loess-like permafrost palaeosol sequence in NE Siberia, Geoderma, 143, 281-295, 2008.

Zech, M., Buggle, B., Leiber, K., Markovic, S., Glaser, B., Hambach, U., Huwe, B., Stevens, T., Sümegi, P., Wiesenberg, G., and Zöller, L.: Reconstructing Quaternary vegetation history in the Carpathian Basin, SE Europe, using $n$-alkane biomarkers as molecular fossils: problems and possible solutions, potential and limitations, Eiszeitalter und Gegenwart - Quat. Sci. J., 10 85, 150-157, 2009.

Zech, M., Andreev, A., Zech, R., Müller, S., Hambach, U., Frechen, M., and Zech, W.: Quaternary vegetation changes derived from a loess-like permafrost palaeosol sequence in Northeast Siberia using alkane biomarker and pollen analyses, Boreas, 39, 540-550, 2010.

Zech, M., Pedentchouk, N., Buggle, B., Leiber, K., Kalbitz, K., Markovic, S., and Glaser, B.: Effect of leaf litter degradation and seasonality on $\mathrm{D} / \mathrm{H}$ isotope ratios of $n$-alkane biomarkers, Geochim. Cosmochim. Acta, 75, 4917-4928, 2011a.

Zech, M., Zech, R., Buggle, B., and Zöller, L.: Novel methodological approaches in loess research - interrogating biomarkers and compound-specific stable isotopes, Eiszeitalter und Gegenwart - Quat. Sci. J., 60, 170-187, 2011b.

20 Zech, M., Krause, T., Meszner, S., and Faust, D.: Incorrect when uncorrected: reconstructing vegetation history using $n$-alkane biomarkers in loess-paleosol sequences - a case study from the Saxonian loess region, Germany, Quat. Int., doi:10.1016/j.quaint.2012.01.023, $2012 a$.

Zech, M., Rass, S., Buggle, B., Löscher, M., and Zöller, L.: Reconstruction of the Late Quaternary paleoenvironments of the Nussloch loess paleosol sequence, Germany, using $n$-alkane biomarkers, Quat. Res., doi:10.1016/j.yqres.2012.05.006, 2012b.

Zech, R., Huang, Y., Zech, M., Tarozo, R., and Zech, W.: High carbon sequestration in Siberian permafrost loess-paleosols during glacials, Clim. Past, 7, 501-509, doi:10.5194/cp-7-5012011, 2011.

Zech, R., Gao, L., Tarazo, R., and Huang, Y.: Branched GDGTs in Pleistocene loess-paleosol sequences: three case studies, Org. Geochem., resubmitted, 2012.

\section{BGD}

9, 9875-9896, 2012

\section{n-Alkane lipid biomarkers in loess}

M. Zech et al.

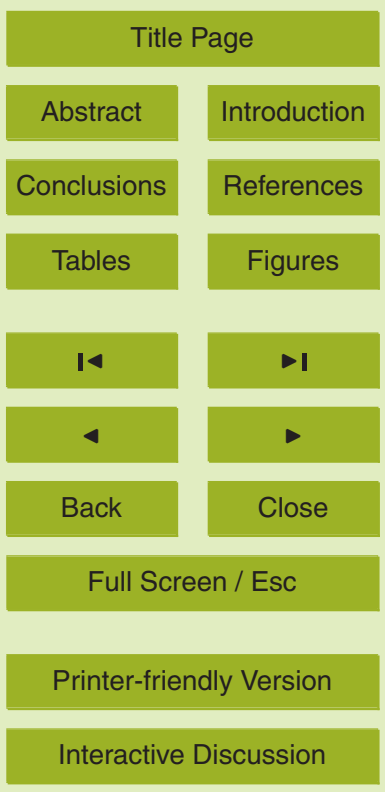


Zhang, Z., Zhao, M., Eglington, G., Lu, H., and Huang, C.: Leaf wax lipids as paleovegetational and paleoenvironmental proxies for the Chinese Loess Plateau over the last $170 \mathrm{kyr}$, Quat. Sci. Rev., 20, 575-594, 2006.

Zöller, L. and Faust, D.: Lower latitudes loess - dust transport past and present, special issue in: Quat. Int., 196, 1-160, 2009.

Zöller, L. and Pernicka, E.: A note on overcounting in alpha-counters and its elimination, Ancient TL, 7, 11-14, 1989.

\section{BGD}

9, 9875-9896, 2012

\section{n-Alkane lipid biomarkers in loess}

M. Zech et al.

Title Page

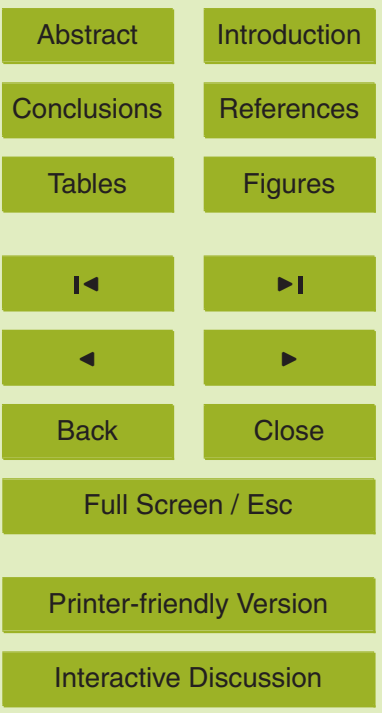


BGD

9, 9875-9896, 2012

\section{n-Alkane lipid biomarkers in loess}

Table 1. Results of radiocarbon analyses of blanks and $n$-alkane samples.

\begin{tabular}{|c|c|c|c|c|c|c|c|c|}
\hline $\begin{array}{l}\text { Sample } \\
\text { code }\end{array}$ & $\begin{array}{l}\text { Sample name } \\
\text { and treatment }\end{array}$ & Material & $\mathrm{pMC}$ & $\begin{array}{l}\delta^{13} \mathrm{C} \\
(\% \circ)\end{array}$ & $\begin{array}{c}{ }^{14} \mathrm{C} \text { age } \\
\text { (kyr) }\end{array}$ & $\begin{array}{l}\text { Error } \\
\text { (kyr) }\end{array}$ & $\begin{array}{c}\text { Calibrated } \\
\text { Age }^{1}\left(\mathrm{kyr}^{2} \mathrm{cal} \mathrm{BP}\right)\end{array}$ & $\begin{array}{l}68 \% \text { range } \\
\text { (kyr cal BP) }\end{array}$ \\
\hline Poz-43739 & $\mathrm{P} 1347+\mathrm{DCM}$ & fossil coal & 1.38 & -22.4 & & & & \\
\hline Poz-44077 & Bckg + DCM & fossil coal & 0.65 & -19.1 & & & & \\
\hline Poz-44078 & Bckg + DCM & fossil coal & 1.69 & -24.1 & & & & \\
\hline Poz-44359 & $\mathrm{P} 1347 \mathrm{~A}+\mathrm{DCM}+\mathrm{alk}+\mathrm{H}_{2} \mathrm{O}$ & fossil coal & 0.28 & -28.3 & & & & \\
\hline Poz-43042 & Sib1 + DCM & alkanes from very old sediments & 2.58 & -27.6 & & & & \\
\hline Poz-43449 & Sib1/1 + DCM & alkanes from very old sediments & 4.14 & -28.9 & & & & \\
\hline Poz-43738 & Sib2 + DCM & alkanes from very old sediments & 1.71 & -22.9 & & & & \\
\hline Poz-45758 & $\mathrm{Sib} 3+\mathrm{DCM}+\mathrm{alk}+\mathrm{H}_{2} \mathrm{O}$ & alkanes from very old sediments & 2.53 & -46.7 & & & & \\
\hline Poz-45759 & $\mathrm{Sib} 4+\mathrm{DCM}+\mathrm{alk}+\mathrm{H}_{2} \mathrm{O}$ & alkanes from very old sediments & 2.27 & -32.0 & & & & \\
\hline Poz-46748 & sample $15+\mathrm{DCM}+$ alk $+\mathrm{H}_{2} \mathrm{O}$ & alkanes from sediments & $12.1^{2}$ & -35.8 & 16.97 & 0.53 & 20.34 & $19.64-21.05$ \\
\hline Poz-46749 & sample $19+\mathrm{DCM}+$ alk $+\mathrm{H}_{2} \mathrm{O}$ & alkanes from sediments & $4.75^{2}$ & -32.8 & 24.47 & 1.29 & 29.16 & $27.78-30.54$ \\
\hline Poz-46750 & sample $21+\mathrm{DCM}+$ alk $+\mathrm{H}_{2} \mathrm{O}$ & alkanes from sediments & $10.07^{2}$ & -37.5 & 18.44 & 0.62 & 22.07 & $21.29-22.84$ \\
\hline Poz-46751 & sample $23+\mathrm{DCM}+$ alk $+\mathrm{H}_{2} \mathrm{O}$ & alkanes from sediments & $4.36^{2}$ & -36.0 & 25.16 & 1.42 & 29.83 & $28.39-31.26$ \\
\hline
\end{tabular}

${ }^{1}$ Calibration was done with quickcal2007 vers.1.5 (Danzeglocke et al., 2012). ${ }^{2}$ With correction for background $2.4 \pm 0.8 \mathrm{pMC}$, assuming a $2.4 \%$ contamination of the samples with modern carbon $(\sim 100 \mathrm{pMC})$.

\section{Zech et al.}

Title Page

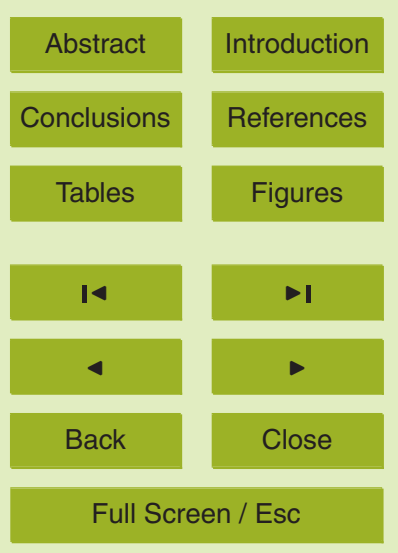

Printer-friendly Version

Interactive Discussion 
BGD

9, 9875-9896, 2012

Table 2. Measured pMC values of the $n$-alkane fractions, sedimentation OSL ages, estimated uncalibrated syn-sedimentary ${ }^{14} \mathrm{C}$ ages, post-sedimentary pMC values and calculated percentages of post-sedimentary $n$-alkane contamination by roots.

\begin{tabular}{|c|c|c|c|c|c|c|c|c|}
\hline $\begin{array}{l}\text { Sample } \\
\text { name }\end{array}$ & $\mathrm{pMC}_{\text {measured }}$ & $\begin{array}{l}\text { Sedimentation } \\
\text { OSL age (kyr) }\end{array}$ & $\begin{array}{c}\text { Estimated } \\
\text { uncalibrated } \\
\text { syn-sedimentary } \\
{ }^{14} \mathrm{C}_{\text {ages }}{ }^{*}(\mathrm{kyr})\end{array}$ & $\mathrm{pMC}_{\text {syn-sedimentary }}$ & $\begin{array}{c}\text { Suspected } \\
\text { time of } \\
\text { contamination } \\
\left(\text { kyrkyrcalBP }{ }^{-1}\right)\end{array}$ & $\mathrm{pMC}_{\text {post-sedimentary }}$ & $\begin{array}{l}\text { Percentage } \\
\text { root- } \\
\text { contamination }\end{array}$ & $\begin{array}{c}\text { Error } \\
\text { range } \\
\text { based on } \\
\text { OSL errors }\end{array}$ \\
\hline \multirow{5}{*}{ Sample 15} & \multirow{5}{*}{12.10} & \multirow{5}{*}{$26.5 \pm 3.1$} & \multirow{5}{*}{22.1} & \multirow{5}{*}{6.31} & current & 100 & $6 \%$ & $3-8 \%$ \\
\hline & & & & & last decades & 120 & $5 \%$ & $2-7 \%$ \\
\hline & & & & & $3.0 / 2.85$ & 70.1 & $9 \%$ & $4-12 \%$ \\
\hline & & & & & $6.0 / 5.2$ & 52.3 & $13 \%$ & $6-16 \%$ \\
\hline & & & & & $9.0 / 8.1$ & 36.5 & $19 \%$ & $10-24 \%$ \\
\hline \multirow[t]{2}{*}{ Sample 19} & \multirow[t]{3}{*}{4.75} & \multirow[t]{3}{*}{$27.3 \pm 3.0$} & 22.6 & 6.00 & & & none & \\
\hline & & & \multirow{5}{*}{27.4} & \multirow{5}{*}{3.30} & current & 100 & $7 \%$ & $5-8 \%$ \\
\hline \multirow{4}{*}{ Sample 21} & & & & & last decades & 120 & $6 \%$ & $4-7 \%$ \\
\hline & \multirow[t]{3}{*}{10.07} & \multirow[t]{3}{*}{$32.0 \pm 3.5$} & & & $3.0 / 2.85$ & 70.1 & $10 \%$ & $8-12 \%$ \\
\hline & & & & & $6.0 / 5.2$ & 52.3 & $14 \%$ & $11-16 \%$ \\
\hline & & & & & $9.0 / 8.1$ & 36.5 & $20 \%$ & $16-23 \%$ \\
\hline \multirow{5}{*}{ Sample 23} & \multirow{5}{*}{4.36} & \multirow{5}{*}{$45.6 \pm 5.3$} & \multirow{5}{*}{42.0} & \multirow{5}{*}{0.54} & current & 100 & $4 \%$ & $3-4 \%$ \\
\hline & & & & & last decades & 120 & $3 \%$ & $3-3 \%$ \\
\hline & & & & & $3.0 / 2.85$ & 70.1 & $5 \%$ & $5-6 \%$ \\
\hline & & & & & $6.0 / 5.2$ & 52.3 & $7 \%$ & $6-8 \%$ \\
\hline & & & & & $9.0 / 8.1$ & 36.5 & $11 \%$ & $9-11 \%$ \\
\hline
\end{tabular}

${ }^{*}$ Assuming that $\mathrm{OSL}$ age $=$ calibrated ${ }^{14} \mathrm{C}$ age and using quickcal2007 vers.1.5 (Danzeglocke et al., 2012).

\section{n-Alkane lipid biomarkers in loess}

M. Zech et al.

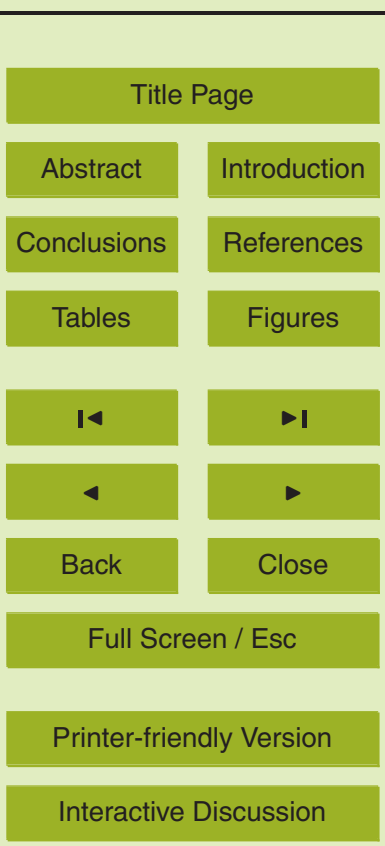


BGD

9, 9875-9896, 2012

n-Alkane lipid biomarkers in loess

M. Zech et al.

Table 3. OSL quartz fine grain age estimates.

\begin{tabular}{lccccc}
\hline Sample & Depth $(\mathrm{m})$ & $n$ & Fit & $D_{\mathrm{e}}(\mathrm{Gy})$ & Age $(\mathrm{kyr})$ \\
\hline BT835 & 2.9 & $12 / 12$ & EXP + LIN & $80.4 \pm 0.69$ & $24.5 \pm 2.7$ \\
BT836 & 3.4 & $12 / 12$ & EXP + LIN & $71.04 \pm 1.14$ & $22.9 \pm 2.6$ \\
BT837 & 5.3 & $12 / 12$ & EXP + LIN & $89.73 \pm 1.72$ & $26.5 \pm 3.1$ \\
BT838 & 6.2 & $12 / 12$ & EXP + LIN & $88.17 \pm 0.92$ & $28.0 \pm 3.0$ \\
BT839 & 7.9 & $12 / 12$ & EXP + LIN & $87.71 \pm 0.99$ & $26.6 \pm 2.9$ \\
BT840 & 9.8 & $12 / 12$ & EXP + LIN & $132.91 \pm 1.33$ & $39.0 \pm 4.4$ \\
BT842 & 10 & $12 / 12$ & EXP + LIN & $161.38 \pm 1.25$ & $45.6 \pm 5.3$ \\
BT844 & 10.8 & $12 / 12$ & EXP + LIN & $235.46 \pm 2.41$ & $72.8 \pm 8.1$ \\
\hline
\end{tabular}

Note: Ages given as mean with 2-sigma uncertainty. 


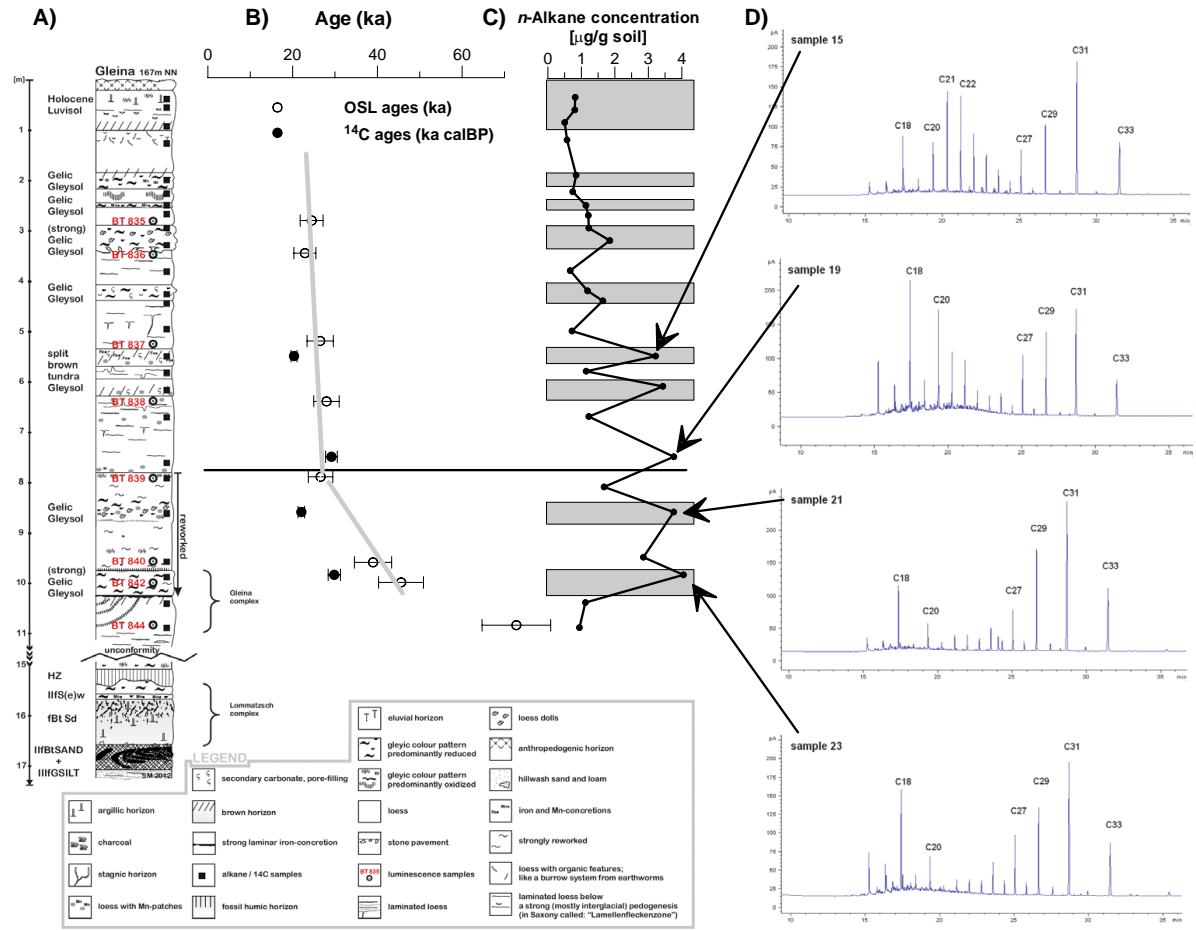

Fig. 1. (A) Stratigraphy of the Gleina loess-paleosol sequence. (B) Age-depth profile of calibrated radiocarbon ages and OSL ages including error bars. (C) $n$-Alkane concentrations (from M. Zech et al., 2012b) and (D) GC-FID $n$-alkane chromatograms for the four radiocarbon-dated $n$-alkane samples.

\section{BGD}

\section{9, 9875-9896, 2012}

\section{n-Alkane lipid biomarkers in loess}

\section{Zech et al.}

\section{Title Page}

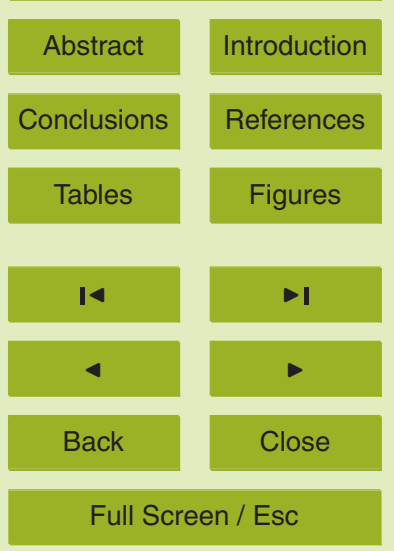

Printer-friendly Version

Interactive Discussion 